\title{
Cohort study of ageing from Bagé (SIGa-Bagé), Brazil: profile and methodology
}

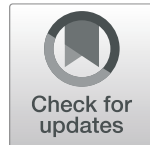

Elaine Thumé1* (1), Marciane Kessler ${ }^{1,2}$, Karla P. Machado ${ }^{1}$, Bruno P. Nunes ${ }^{1}$, Pamela M. Volz³, Louriele S. Wachs ${ }^{1}$, Mariangela U. Soares ${ }^{1}$, Mirelle O. Saes ${ }^{5}$, Suele M. Duro ${ }^{1}$, Alitéia Santiago Dilélio ${ }^{1}$ and Luiz A. Facchini ${ }^{1,4}$

\begin{abstract}
Background: The Bagé Cohort Study of Ageing is a population-based cohort study that has recently completed the first follow-up of a representative sample of older adults from Bagé, a city with more than 100,000 inhabitants located in the state of Rio Grande do Sul, Brazil. This is one of the first longitudinal studies to assess the impact of primary health care coverage on health conditions and inequalities. Our aim is to investigate the prevalence, incidence and trends of risk factors, health behaviours, social relationships, non-communicable diseases, geriatric diseases and disorders, hospitalisation, self-perceived health, and all-cause and specific-cause mortality. In addition, we aim to evaluate socioeconomic and health inequalities and the impact of primary health care on the outcomes under study.

Methods/design: The study covers participants aged 60 or over, selected by probabilistic (representative) sampling of the urban area of the city of Bagé, which is covered by Primary Health Care Services. The baseline examination included 1593 older adults and was conducted from July 2008 to November 2008. After eight to nine years (2016/2017), the first follow-up was conducted from September 2016 to August 2017. All participants underwent an extensive core assessment programme including structured interviews, questionnaires, cognitive testing (baseline and follow-up), physical examinations and anthropometric measurements (follow-up).

Results: Of the original participants, 1395 (87.6\%) were located for follow-up: 757 elderly individuals (47.5\%) were re-interviewed, but losses in data transfer occurred for 22. The remaining 638 (40.1\%) had died. In addition, we had 81 (5.1\%) refusals and 117 (7.3\%) losses. Among the 1373 older adults who were followed down, there was a higher proportion of female interviewees ( $p=0.042$ ) and a higher proportion of male deaths ( $p=0.001$ ) in $2016 / 2017$. There were no differences in losses and refusals according to gender $(p=0.102)$. There was a difference in average age between the interviewees (68.8 years; $S D \pm 6.5)$ and non-interviewees (73.2 years; $S D \pm 9.0)(p<0.001)$. Data are available at the Department of Social Medicine in Federal University of Pelotas, Rio Grande do Sul, Brazil, for any collaboration.
\end{abstract}

Keywords: Cohort study, Epidemiology, Population based, Older adults, Health status, Health inequalities, Primary health care, SIGa-Bagé, Brazil

*Correspondence: elainethume@gmail.com

${ }^{1}$ Post-Graduate Programme in Nursing, Federal University of Pelotas, Pelotas,

Brazil

Full list of author information is available at the end of the article

(c) The Author(s). 2021 Open Access This article is licensed under a Creative Commons Attribution 4.0 International License, which permits use, sharing, adaptation, distribution and reproduction in any medium or format, as long as you give appropriate credit to the original author(s) and the source, provide a link to the Creative Commons licence, and indicate if changes were made. The images or other third party material in this article are included in the article's Creative Commons licence, unless indicated otherwise in a credit line to the material. If material is not included in the article's Creative Commons licence and your intended use is not permitted by statutory regulation or exceeds the permitted use, you will need to obtain permission directly from the copyright holder. To view a copy of this licence, visit http://creativecommons.org/licenses/by/4.0/. The Creative Commons Public Domain Dedication waiver (http://creativecommons.org/publicdomain/zero/1.0/) applies to the data made available in this article, unless otherwise stated in a credit line to the data. 


\section{Introduction}

Challenges related to ageing, such as the increased demand for health care and welfare [1], are a global concern. These issues are particularly pressing in middle- and low-income countries, which will be home to $80 \%$ of the population older than 60 years by 2050 [2].

Brazil has the fifth largest population in the world distributed over an extensive territory. Together with China and India, Brazil has slightly more than 20 years to adapt to an increase in the proportion of the population aged 60 years or older from $10 \%$ to $20 \%$. France, for example, has approximately 150 years to adapt to this demographic change [2]. In Brazil, the proportion of people aged 60 years or older was $12.6 \%$ in 2017 , and this value is projected to reach $29.6 \%$ by 2050 [3]. This change indicates a rapid ageing of the population in a context of limited resources and one of the largest levels of socioeconomic inequality (Gini coefficient $=0.53$ in 2017) $[4,5]$.

Health status tends to be worse among older people, particularly in poorer countries $[6,7]$, where there is increased exposure to risk factors for chronic diseases [8] and premature morbidity and mortality $[1,9]$. However, infectious/communicable diseases and external causes are still problems in low- and middle-income countries $[1,10]$.

In this context, data from longitudinal studies have the potential to support and evaluate short- and longterm social and health policies for elderly individuals [11]. Population-based longitudinal studies on this topic include a cohort study performed in Bambuí city, Minas Gerais, known as the Bambuí Cohort Study of Ageing [12]; a study in São Paulo known as the Study Health, Welfare and Aging (SABE) study [13]; the Epidemiology of the Older Adult (Epidoso) study [14]; an ageing cohort study in Florianópolis known as the EpiFloripa study [15]; and one recently for the entire country of Brazil, known as The Brazilian Longitudinal Study of Ageing (ELSI-Brazil) study) [11].

Nevertheless, the Bagé Cohort Study of Ageing (SIGaBagé Study) is the first population-based longitudinal study of elderly individuals aged 60 years or older to consider the association of health indicators in elderly individuals with primary health care (PHC) services. The study permits the evaluation of the prevalence, incidence and temporal trends of risk factors, health behaviours, social relationships, non-communicable diseases, geriatric diseases and disorders, self-perceived health and hospitalisation. It is possible to measure patterns of mortality, to determine its main causes, to measure survival and to identify temporal trends in socioeconomic inequalities and impacts on health. Finally, the study enables us to assess the influence of different models of health care - the traditional model and the Family Health Strategy (FHS)
- on the outcomes under study and their ability to promote health equity, which sets this cohort apart from most others.

The FHS was decisive for the expansion and consolidation of PHC in Brazil. This programme was developed during the 1990s to reorganise and restructure the health system [16, 17]. The FHS has multidisciplinary teams, including community health workers, that are responsible for meeting the heath care needs of approximately 1000 households in a defined geographical area, bringing health care closer to where people live and work $[17,18]$. The team delivers a range of services, including acute care, comprehensive and longitudinal healthcare, risk factor management, and referrals, and prioritises actions for health promotion, disease prevention and recognition of the health and social needs of the registered population and families $[17,18]$. Professionals also deliver home health care for those who are unable to reach health services, such as those who are bedridden or have other serious health conditions [17]. Municipal governments are responsible for FHS service provision, but the majority of funding comes from the federal government.

FHS coverage is currently $63.9 \%$, but is higher in rural areas and the poorest regions in order to reduce health inequalities [19]. The rest of the population has access to traditional primary health care (TPHC). TPHC teams do not have a fixed structure; contain more medical professionals, sometimes including specialists such as paediatricians, obstetricians and gynaecologists; do not serve a defined number of families or geographical area; and do not usually include community health workers [17]. TPHC focuses on specific diseases, dispenses curative care and acts on emerging demands, with little ability to solve health problems related to family and social issues [17].

Studies have shown that the FHS provides superior service performance compared with the traditional primary care model, particularly in terms of better quality of care $[20,21]$, reduced number of hospitalisations due to conditions sensitive to primary care [22,23], reduced mortality due to cardiovascular disease [24] and increased access and use of health services and prevention, thus promoting health equity $[17,25]$.

The SIGa-Bagé baseline study was conducted in 2008, when the FHS covered $51 \%$ of the population in the urban area. Municipal management began to invest in the conversion of the traditional model to the FHS in 2003, and in the last 15 years, expansion with a consequent increase in access to health services has occurred, with $71.0 \%$ of the population now covered by the FHS [19]. 


\section{Methods/Design}

\section{Where is it located and why?}

The municipality of Bagé is located in the state of Rio Grande do Sul (RS), on the southern edge of Brazil; it had an estimated population of 121,143 inhabitants in 2019 and a demographic density of 28.52 inhabitants $/ \mathrm{km}^{2}$ according to the 2010 Census [26]. The municipality is located just over $350 \mathrm{~km}$ from Porto Alegre (state capital) and approximately $190 \mathrm{~km}$ from Pelotas city, where the Federal University of Pelotas is located. It is bordered by Uruguay to the south and is the headquarters of the Seventh Regional Health Coordination. The main economic activity in the municipality is agriculture.

In 2010, the Municipal Human Development Index (MHDI) of Bagé was 0.740, which is considered high (MHDI between 0.700 and 0.799), similar to that of RS $(\mathrm{HDI}=0.746)$ and of the entire country $(\mathrm{HDI}=0.727)$. The dimension that most contributes to the municipal HDI is longevity (0.848), followed by income (0.739) and education (0.647) [27]. Bagé had Gross Domestic Product (GDP) of approximately R $\$ 21930.77$ per capita/year in 2016 [26].

Bagé municipality was chosen as the study area in 2008 based on the coverage rate of FHS (51.0\%), which was the highest among all municipalities with over 100,000 inhabitants in the state of RS. In addition, the proportion of individuals aged 60 years or older (12.0\%) was similar to the percentage found in RS (12.6\%) but higher than that of the country as a whole (10.0\%) [28].

\section{Who is included in the cohort?}

The cohort consists of individuals aged 60 years or older living in private households in the urban area of Bagé municipality. In 2008, the sample size was calculated to study the "need for home care" and "home care received" $[17,29]$.

The prevalence of "need for home care" was calculated considering a population size of 14,792 elderly individuals in Bagé [28], a 95\% confidence level, an estimated prevalence of the outcome of $20 \%$ and an acceptable error of $3 \%$, resulting in a sample size of 653 elderly individuals. To calculate the prevalence of "home care received", a population size of 3,000 elderly individuals with a need for home care, a 95\% confidence level, an estimated prevalence of the outcome of $60 \%$ and an acceptable error of $4 \%$ were considered, resulting in a sample size of 483 elderly individuals. The calculation of associations considered a confidence level of $95 \%$, a statistical power of $80 \%, 10 \%$ for losses and refusals, $15 \%$ for control of confounding factors and a design effect of 1.26 to detect relative risks of at least 1.5 exposures affecting up to $4 \%$ of the population. Thus, the total sample required for the study in 2008 was 1,530 individuals.

To locate the sample, basic health units were visited, and the teams were asked to demarcate the coverage areas on a map provided by the Brazilian Institute of Geography and Statistics (IBGE). These areas were divided into micro-areas: each block within the micro-area was numbered, and each quadrant of the block was identified for a subsequent draw of the starting point for data collection. After the draw, the household was visited, and the resident was asked about the presence of elderly individuals (60 years or older) in the household. One out of every six households was included, which allowed random identification of the individuals eligible for the study. No replacements were admitted. All elderly residents in the selected households were invited to participate in the study. Field workers made at least three attempts to interview household members. Ultimately, 1,713 elderly household members were identified, and a total of 1,593 were interviewed, for a response rate of 93\% (Fig. 1). Refusals represented $3 \%(n=44)$ (FHS $=27.3 \%$ and traditional $=72.7 \%)$ and losses $4 \%(\mathrm{n}=76)(\mathrm{FHS}=27.6 \%$ and traditional $=72.4 \%$ ) of the identified household members $[17,29]$.

Losses and refusals were higher in wealthier areas of the city (traditional) and were mainly men, who often work all day, particularly in rural areas; some were travelling, and others had changed address or were hospitalised. However, considering the size of losses and refusals, no major effects are expected on the study's estimates.

In 2016, follow-up of the individuals who had been interviewed in 2008 was conducted to establish a population-based longitudinal study. For both follow-ups, individuals who, at the time of the interview, were travelling, deprived of their liberty by judicial decision or living in long-term care facilities were excluded. Interviews not performed after three attempts on different days and times were considered losses/refusals, and no substitutions were allowed. In case of any cognitive or communication impairment of an elderly individual, the questionnaire was administered to the caregiver, excluding the questions about self-perception and self-assessment. During follow-up, the elderly individual was invited to answer the questionnaire with the possibility of rescheduling. For those not located, neighbours and health services were consulted regarding the current address or death of the elderly individual.

The list of deaths identified during the data collection was sent to the Health State Department for confirmation of the data and cause of death using the Mortality Information System, and a data use agreement was signed.

The structured questionnaire with pre-coded questions and the instruction manual were tested in a pilot study using individual interviews of elderly individuals in a longterm care facility. This strategy also enabled the practical training and selection of interviewers in July 2008 and September 2016. In the baseline study, the questionnaire was applied in paper format, whereas in the follow-up 


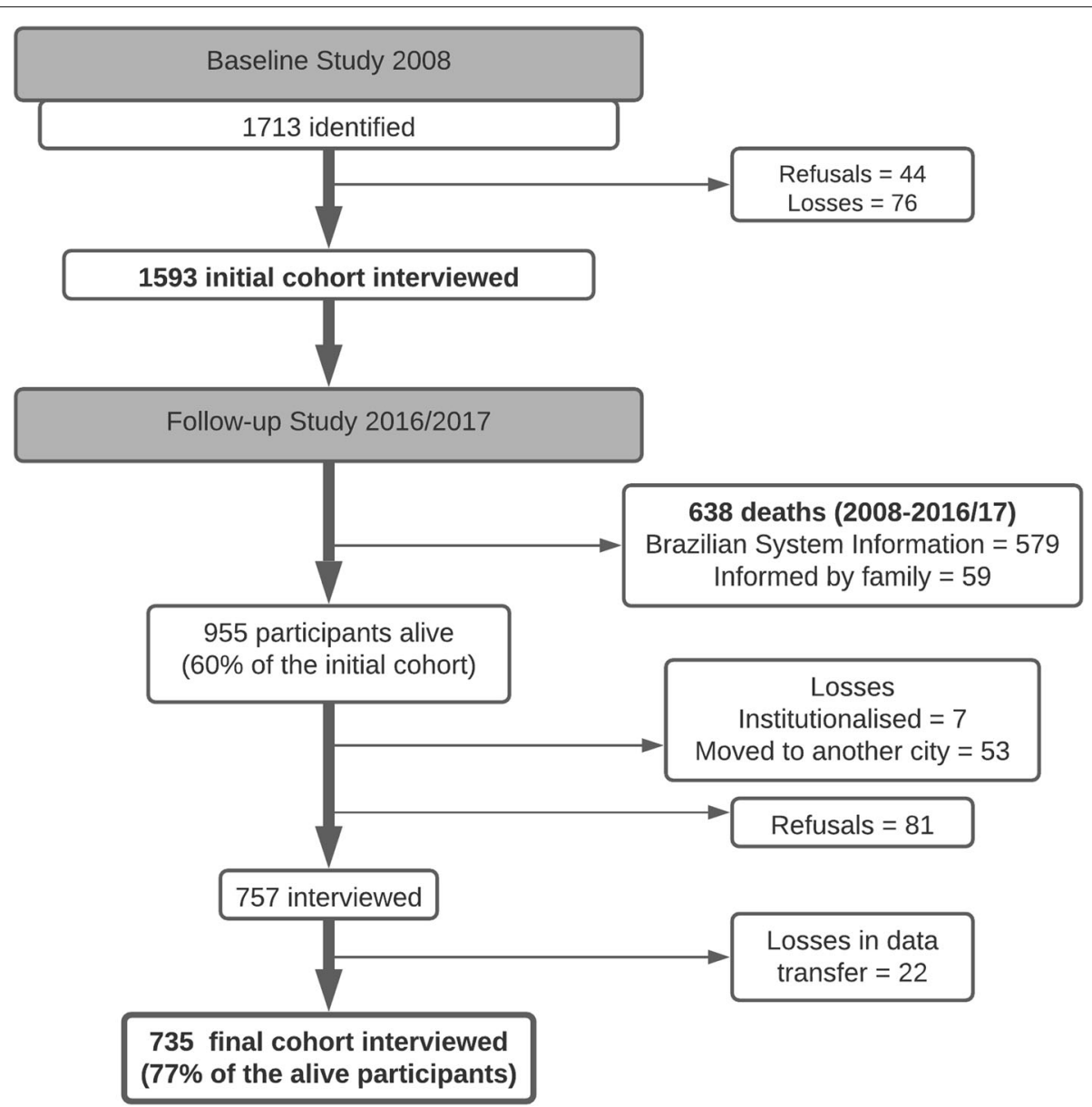

Fig. 1 Sample recruitment process in the Bagé Cohort Study of Ageing, 2008-2016/2017. Pelotas, 2021

study, it was applied in an electronic format using a Mio P550B personal digital assistant (PDA).

Anthropometric measurements at follow-up were assessed based on the techniques proposed by Lohman [30]. Weight was measured on a Tanita $\left({ }^{\circ}\right.$ digital scale, model UM-080, with a maximum capacity of $150 \mathrm{~kg}$ and a precision of 100 g; elderly individuals were weighed wearing light clothing and while barefoot. Knee height was obtained using an Indaiá $®$ wooden stadiometer for children, with a 100-centimetre scale graduated in millimetres; for this purpose, the individual was asked to remain seated while barefoot and to keep the knee flexed at a $90^{\circ}$ angle.

Waist circumference (WC) and calf circumference (CC) were measured using an inextensible anthropometric tape. For WC, the interviewee faced the examiner while standing and lifted their shirt up to the lower edge of the nipples; the tape was then placed around the waist of the individual at the midpoint between the lower edge of the last rib and the iliac crest with $0.1-\mathrm{cm}$ precision. CC was measured at the maximum horizontal distance around the calf. To measure grip strength, a JAMAR $($ device with a precision of $150 \mathrm{~cm}$ was used. The elderly individual was seated with the arm close to the body and in a $90^{\circ}$ flexed position, and grip movement was measured three times for each hand.

Blood pressure was measured using an Omron $\AA$ device, model HEM-6123, and the measurement was standardised on the left arm. The first measurement was taken 15 minutes after beginning the interview, and two other measurements were taken at the end of the questionnaire. All devices used for anthropometric measurements were registered at the National Institute of Metrology, Quality and Technology (INMETRO).

The study was advertised in the municipality through radio interviews, articles in local newspapers and the creation of a page on a social network site to reduce the number of refusals and losses.

Ethical principles were ensured, and the interviewees or their guardians were asked to sign an informed consent form. The right not to participate in the study and the anonymity of the interviewees were ensured. This 
cohort study project was submitted to the Brazil Platform and approved by the Research Ethics Committee at Federal University of Pelotas under number 678,664 and was granted a Certificate of Ethical Appreciation under number 31497314000005317.

\section{Cohort waves: what has been measured?}

To date, two data collections have been performed: the first was conducted from July to November 2008 (baseline), and the second was conducted from September 2016 to August 2017 (follow-up).

In 2008, data were collected about social and health conditions and utilisation of health care services, including socioeconomic, demographic, behavioural, home care, morbidity, functional capacity, self-perception of health, support network, feeding guidelines, physical activity and anthropometric (self-reported) data. The following validated instruments were used in both collections: the International Physical Activity Questionnaire (IPAQ SHORT) [31], the Katz Index of Independence in Activities of Daily Living (Katz ALD) [32], the Lawton Instrumental Activities of Daily Living Scale (IADL) [33], the Geriatric Depression Scale (GDS) [34], and the Mini Mental State Examination (MMSE) [35]. The following instruments were included in the follow-up: the Quality of Life Assessment (WHOQOL-BREF) [36], the Patient Health Questionnaire (PHQ-9) [37], the Patient Assessment of Chronic Illness Care (PACIC) [38], the Vulnerability to Abuse Screening Scale (VASS) [39], the Medical Outcomes Study's Social Support Scale [40], and other questions developed specifically for the study (Additional file 1: Questionnaire).

The follow-up was planned to collect the same baseline data and some new variables, including complementary instruments and/or questions related to support and social support, stressful events, risk of abuse, quality of life and anthropometric measurements.

Among the interviews conducted, $10 \%$ were randomly selected for quality control via telephone. For that purpose, 14 key questions were selected from the original questionnaire, in addition to four questions to be completed by the researcher. This approach allowed the identification of possible errors and/or fabricated responses, with the objective of evaluating intra-observer reliability. The phone calls were made within two weeks of the interview.

\section{Results}

Of the 1593 elderly individuals in the baseline study, 1395 (87.6\%) were located for follow-up: 757 elderly individuals $(47.5 \%)$ were re-interviewed (FHS $=54.7 \%$ and traditional $=45.3 \%$ ), with 22 losses in data transfer; 579 deaths were confirmed by the Brazilian System of Information on Mortality (SIM) until August 2017, and 59 deaths were reported by the family or neighbours but were not located in the SIM, giving a total of 638 deaths (40.1\%) (FHS = $53.4 \%$ and traditional $=46.6 \%)$. Among the participants in 2008, 198 (12.4\%) were not followed up in 2016-2017 $\mathrm{FHS}=49.5 \%$ and traditional $=50.5 \%): 81(5.1 \%)$ were refusals, and 117 (7.3\%) were classified as losses. Among the losses, 57 could not be located, seven were institutionalised, and 53 had moved to another municipality (Fig. 1).

Among the 1373 older adults followed up in 2016/2017 (735 interviews [53.5\%] + 638 deaths [46.5\%]), there was a higher proportion of female interviewees $(48.1 \%$ females and $42.8 \%$ males, $\mathrm{p}=0.042)$ and a higher proportion of male deaths $(45.2 \%$ males and $37.0 \%$ females, $\mathrm{p}=0.001)$. There were no differences in losses and refusals according to gender $(14.9 \%$ women and $12.0 \%$ men, $\mathrm{p}=0.102)$. There was a difference in average age between the interviewees (68.8 years; $\mathrm{SD} \pm 6.5)$ and non-interviewees $(73.2$ years; $\mathrm{SD} \pm 9.0$ ), with a $p$-value $i 0.001$. The overall mortality rate was 72.3 (66.9-78.1) deaths per 1000 person-years over the course of a mean duration of follow-up of 6.4 years (SD: 2.6). Cause of death was ascertained for 579 deaths, and the main specific causes were cardiovascular diseases $(36.9 \%)$, cancer $(23.8 \%)$ and respiratory diseases (12.2\%).

Table 1 shows the demographic, socioeconomic and health behaviours distribution among older adults in the baseline study (2008) and in the follow-up (2016/2017).

Based on the data obtained from the 2008 data collection, $62.8 \%$ of the elderly individuals were female, $51.3 \%$ were married or lived with a partner, $71.7 \%$ were retired, $17.6 \%$ lived alone, and a high proportion had no schooling (24.0\%) and were poor (34.0\%). The 2008 sample has several similarities to the Bagé city profile but is slightly older and female. There is no information available on individual socioeconomic status in the city profile, but skin colour is a useful indicator [26]. In 2016/2017, most of the interviewees were female (65.4\%), $42.2 \%$ were married or lived with a partner, $79.7 \%$ were retired, and $24.1 \%$ lived alone. The proportion of older adults with no schooling $(23.2 \%)$ was similar to that in 2008 , whereas the proportion of poor older adults (46.1\%) was higher.

Among the main results published from the baseline study (2008), 34.1\% of the participants were assessed with cognitive impairment [41], 18.0\% had depressive symptoms [42], 28.0\% reported falls in the year prior to the interview [43], 10.6\% had functional incapacity for Basic Activities of Daily Living, 34.2\% had functional incapacity for Instrumental Activities of Daily Living [44], $37.4 \%$ reported spinal disorders $(91.5 \%$ for more than 12 months) [45], and $20.7 \%$ reported urinary incontinence [46]. The prevalence of multimorbidity was $81.3 \%$ for $\geq 2$ morbidities and $64.0 \%$ for $\geq 3$ morbidities [47]. In addition, $51.0 \%$ of the participants with hypertension and/or 
Table 1 Demographic, socioeconomic and behavioural characteristics at baseline, re-interview, deaths and losses. SIGa-Bagé Cohort, 2008-2016/2017

\begin{tabular}{|c|c|c|c|c|c|c|c|c|}
\hline \multirow[t]{2}{*}{ Variables } & \multicolumn{2}{|c|}{$\begin{array}{l}\text { Baseline } 2008 \\
\text { Cohort } 2008 \\
(n=1593)\end{array}$} & \multicolumn{2}{|c|}{$\begin{array}{c}\text { Re-interview } \\
2016 / 2017 \\
(n=735)\end{array}$} & \multicolumn{2}{|c|}{$\begin{array}{c}\text { Deaths } \\
2008-2017 \\
(n=638)\end{array}$} & \multicolumn{2}{|c|}{$\begin{array}{c}\text { Losses and } \\
\text { Refusals } 2017 \\
\quad(n=220)\end{array}$} \\
\hline & $\mathbf{n}$ & $\%$ & $\mathrm{n}$ & $\%$ & $\mathrm{n}$ & $\%$ & $\mathrm{n}$ & $\%$ \\
\hline \multicolumn{9}{|l|}{ Gender } \\
\hline Male & 593 & 37.2 & 254 & 34.6 & 268 & 42.0 & 71 & 32.3 \\
\hline Female & 1000 & 62.8 & 481 & 65.4 & 370 & 58.0 & 149 & 67.7 \\
\hline \multicolumn{9}{|l|}{ Age (2008) } \\
\hline 60 to 64 years & 400 & 25.1 & - & - & 99 & 15.5 & 75 & 31.5 \\
\hline 65 to 74 years & 696 & 43.7 & 309 & 42.0 & 223 & 35.0 & 106 & 48.2 \\
\hline 75 years or older & 497 & 31.2 & 426 & 58.0 & 316 & 49.5 & 39 & 17.7 \\
\hline \multicolumn{9}{|l|}{ Self-reported colour } \\
\hline White & 1252 & 78.6 & 604 & 82.2 & 501 & 78.5 & 174 & 79.1 \\
\hline Black/Brown/Indigenous/Yellow & 341 & 21.4 & 131 & 17.8 & 137 & 21.5 & 46 & 20.9 \\
\hline With partner & 816 & 51.3 & 310 & 42.2 & 292 & 45.8 & 124 & 56.6 \\
\hline Live alone & 280 & 17.6 & 177 & 24.1 & 113 & 17.7 & 41 & 18.6 \\
\hline Retiree & 1142 & 71.7 & 584 & 79.7 & 471 & 73.8 & 151 & 68.6 \\
\hline \multicolumn{9}{|l|}{ Education level } \\
\hline Iliterate & 382 & 24.0 & 175 & 27.5 & 175 & 27.5 & 54 & 24.6 \\
\hline 1 to 7 years & 868 & 54.5 & 348 & 54.6 & 348 & 54.6 & 107 & 48.6 \\
\hline 8 years & 342 & 21.5 & 114 & 17.9 & 114 & 17.9 & 59 & 26.8 \\
\hline \multicolumn{9}{|l|}{ Economic classification* } \\
\hline A/B (Richest) & 429 & 27.1 & 105 & 14.6 & 138 & 21.9 & 73 & 33.5 \\
\hline C & 615 & 38.9 & 283 & 39.3 & 256 & 40.6 & 82 & 37.6 \\
\hline D/E (Poorest) & 537 & 34.0 & 332 & 46.1 & 236 & 37.5 & 63 & 28.9 \\
\hline Smokers & 244 & 15.3 & 68 & 9.3 & 97 & 16.8 & 40 & 14.4 \\
\hline Alcohol consumption & 254 & 16.0 & 105 & 14.4 & 61 & 10.6 & 45 & 16.3 \\
\hline
\end{tabular}

* Brazilian Economic Classification Criteria.

diabetes had weak informal relationships (little contact with friends, neighbours and relatives) [48], 69\% of the elderly individuals reported having pets [49], and $32.9 \%$ of the elderly individuals who used medication were classified as having low adherence to treatment [50]. The rate of home health care utilisation was $7 \%$ but was significantly higher in areas with FHS coverage compared to areas covered by TPHC [17]. Nursing staff provided most home care within the FHS, and two-thirds of the elderly individuals who requested home care reported improved health status [29]. Overall, 17.7\% had been hospitalised, and $10.6 \%$ had experienced non-surgical hospitalisation in the last year prior to the interview [51]. The vast majority of these papers presented social and health inequalities.

To date, four theses (about the incidence of depression, association between social relationships and mortality, quality of health care for chronic conditions, mortality in older adults and the role of the FHS in promoting health equity) and one dissertation (occurrence of urinary incontinence) have been finalised using data from the cohort study. In addition, three further theses and one dissertation are in progress that address nutritional status and mortality; the incidence of functional disability; falls and mortality; and recently, coronavirus disease 2019 (COVID-19).

Two papers were recently published, and one was accepted; these papers report results from the cohort study and longitudinal analysis [52-54]. In a study comparing SIGa-Bagé and The English Longitudinal Study of Ageing, Kessler et al. [52] verified that mortality rates were higher in SIGa-Bagé, with physical inactivity and current smoking having the strongest association in both cohorts. A clear graded relationship between the number of risk factors and subsequent mortality was found, with wealth gradients of mortality in both cohorts [52]. In a study of social relationships and survival, Soares et al. 
[53] found that older adults who went out of their homes daily had considerably lower mortality and that going to parties had a protective effect for survival. The lower risk of death for women was modified when the older adults lived in households with two or more people [53]. Another study from Kessler et al. [54] identified that the FHS modified the effect of wealth on mortality, reducing social inequalities in mortality among older adults [54].

\section{Discussion}

The SIGa-Bagé Study is a longitudinal, population-based study with a low probability of selection bias due to probabilistic sampling and population distribution in the territory. It was expected that the female population represented $59 \%$ of the total population with 60 years or older. However, our study enrolled $62.3 \%$ of women, showing a slight female over representation in the cohort. In addition, the nine-year follow-up period and low number of losses and refusals are notable. This is one of the first Brazilian longitudinal studies on ageing with an emphasis on PHC that aims to identify differences in the exposure of health indicators and the impact of health services. The instruments and methods used were consistent with those of the first collection performed, ensuring comparability for most outcomes. New technologies were implemented for data collection, and new thematic areas were added to the study.

The characterisation of the cohort regarding social, psychological and biomedical dimensions, use of health services and mortality will allow the analysis of social gradients in health and mortality and the capacity of health services, especially those of $\mathrm{PHC}$, to promote health equity in such an uneven scenario. In addition, we will be able to recognise mediating mechanisms. The social diversity captured in the cohort will allow an in-depth investigation of health inequalities. These results will be particularly important given the scarcity of investments in health and the scarcity of high-quality and strong evidence on the impact of public health policies in low- and middleincome countries. Results such as these will empower Brazilian's PHC and strengthen the Unified Health System (SUS).

This study also has limitations. The study began by selecting participants aged 60 years or older, which prevents an analysis of the transition of health status from younger to older adults. We did not conduct cohort replacement in 2016/2017 due to the importance of updating the sample to maintain an adequate proportion of participants at the lower end of the age group and facilitate comparison between cohorts. Due to budget constraints, the first follow-up was carried out only after a period of 8-9 years, so the changes that occurred during this time interval were not monitored. Another limitation is the long period of data collection; due to budget constraints, we were not able to hire enough interviewers to collect the data more quickly. Previous personal history information was collected retrospectively; however, cohort studies typically measure exposures before the onset of disease or outcome to avoid reverse causality. Selection and memory biases, which generally affect case and control studies, are also less frequent[55].

Although the results of this study cannot be extrapolated for the country due to socioeconomic and cultural differences by regions, longitudinal studies carried out in other Brazilian regions, states [12-15] and in the country [11] have reported profiles of older adults similar to that in the SIGa-Bagé Study. In this sense, the results can support public policies and health care aimed at promoting healthy ageing and health equity at the local, regional and national levels. Moreover, the results can be used to support permanent education programmes and professional training to improve the quality of health care delivery, especially in PHC services.

\section{Data access and collaboration}

We invite interested parties from national and international institutions to learn more about our cohort and form partnerships and collaborations to build research networks and strengthen skills and capabilities among researchers. Our aim is to build an international research network with a special focus on health inequalities and the role of PHC in promoting health equity. Currently, there is a partnership in place with the Research Department of Epidemiology and Public Health at University College London, England (UK), and the Global Health Institute at Duke University, United States (USA). Analyses and articles are in progress and will be published later in leading international journals.

\section{Abbreviations \\ SIGa-Bagé Study: Bagé (Brazil) Cohort Study of Ageing; PHC: primary health care; FHS: Family Health Strategy; SUS: Brazilian Unified Health System; COVID: coronavirus disease; SIM: Mortality Information System; Cl: confidence interval. IPAQ: International Physical Activity Questionnaire; ALD: Activities of Daily Living; IADL: Instrumental Activities of Daily Living Scale; GDS: Geriatric Depression Scale; MMSE: Mini Mental State Examination; WHOQOL: Quality of Life Assessment; PHQ: Patient Health Questionnaire; PACIC: Patient Assessment of Chronic IIIness Care; VASS: Vulnerability to Abuse Screening Scale; WC: waist circumference; CC: calf circumference; IBGE: Brazilian Institute of Geography and Statistics; PDA: personal digital assistant; RS: Rio Grande do Sul.}

\section{Supplementary Information}

The online version contains supplementary material available at https://doi.org/10.1186/s12889-021-11078-z.

Additional file 1: Questionnaire.

\section{Acknowledgements}

Special thanks are due to all elderly participants in SIGa-Bagé and their families for their valuable contribution to the study; the Universidade da Região da Campanha (URCAMP), which provided the facilities for training the

interviewers and storing the research material; the Health Department of Bagé 
for providing fundamental support in the form of permission and advertising of the study in the municipality; the professionals from the 7a Regional Coordination of Health from the RS Health State Department for support provided at different stages of the study; the Coordination of Improvement of Higher Education Personnel (CAPES) for support for doctoral and master students; and the Brazilian Council for Scientific and Technological Development (CNPq - Process \# 311972/2017-9 -CNPq \# 12/2017) under the Brazilian Ministry of Education and Ministry of Science, Technology, Innovations and Communications.

\section{Authors' contributions}

ET and LAF are the SIGa-Bagé Study coordinators and participated in study conception and design, data acquisition, analysis and interpretation, and drafting the article. MK, BPN, KPM, PMV, LSW and MUS are the study investigators, participated in data acquisition, analysis and interpretation, and wrote the article. SMD, MUS, ASD, BPN and LAF are study investigators and contributed to study conception and design and revision of the article. MOS contributed to the final revision of the article. All authors approved the final version to be published.

\section{Funding}

No funding was received.

\section{Availability of data and materials}

More information on the SIGa-Bagé study and materials can be found on the AQUARES group website: Access and Quality of the Health Care Network https://dms.ufpel.edu.br/aquares/assistencia-domiciliar-a-idosos/ or upon request by contacting Professor Dr Elaine Thumé by email: elainethume@ufpel.edu.br

\section{Declarations}

\section{Ethics approval and consent to participate}

This study was conducted with observance of the National Ethics Committee of Research from Brazil. The study protocol was approved by the Ethics Committee of the Nursing Department at Federal University of Pelotas under number 678,664 and was granted Certificate of Ethical Appreciation 31497314.0.0000.5317. All participants provided signed informed written consent according to the Ethics Committee. The participants can withdraw from the study whenever they wish. Data are stored in a confidential database.

\section{Consent for publication}

Not applicable.

\section{Competing interests}

The authors declare that they have no competing interests.

\section{Author details}

${ }^{1}$ Post-Graduate Programme in Nursing, Federal University of Pelotas, Pelotas, Brazil. ${ }^{2}$ Institute of Health Equity, University College London, London, UK. ${ }^{3}$ Department of Social Medicine, Federal University of Pelotas, Pelotas, Brazil. ${ }^{4}$ Post-Graduate Programme in Epidemiology, Federal University of Pelotas, Pelotas, Brazil. ${ }^{5}$ Post-Graduate Programme in Health Science, Federal University of Rio Grande, Rio Grande, Brazil.

Received: 24 April 2020 Accepted: 17 May 2021

Published online: 07 June 2021

\section{References}

1. Beard J, Bloom D. Towards a comprehensive public health response to population ageing. Lancet. 2015;385(9968):658-61.

2. World Health Organization. Ageing and health. World Health Organ. 2018 https://www.who.int/news-room/fact-sheets/detail/ageing-and-health. Accessed 12 Feb 21.

3. United Nations DepartmentofEconomicandSocialAffairsPD. World Population Ageing 2017 (ST/ESA/SER.A/397). UN. 2017. http://www.un. org/en/development/desa/population/publications/pdf/ageing/ WPA2017_Highlights.pdf. Accessed 12 feb 21.
4. The World Bank. GINI index (World Bank estimate). World Bank. 2017. https://data. worldbank.org/indicator/SI.POV.GINI?end=2017\&locations= BR\&start=2001. Accessed 12 feb 21.

5. Massuda A, Hone T, Leles F, de Castro M, Atun R. The brazilian health system at crossroads: progress, crisis and resilience. BMJ global health. 2018;3(4):

6. Lima-Costa M, De Oliveira C, Macinko J, Marmot M. Socioeconomic inequalities in health in older adults in brazil and england. Am J Public Health. 2012;102(8):1535-41.

7. Umuhoza S, Ataguba J. Inequalities in health and health risk factors in the southern african development community: evidence from world health surveys. Int J Equity Health. 2018;17(1):1-15.

8. de Azevedo Barros MB, Lima M, Medina LdPB, Szwarcwald C, Malta D. Social inequalities in health behaviors among brazilian adults: National health survey, 2013. Int J Equity Health. 2016;15(1):1-10.

9. de Oliveira C, Marmot M, Demakakos P, Vaz de Melo Mambrini J, Peixoto S, Lima-Costa M. Mortality risk attributable to smoking, hypertension and diabetes among english and brazilian older adults (the elsa and bambui cohort ageing studies). Eur J Public Health. 2016;26(5):831-5.

10. Marinho F, de Azeredo Passos VM, Malta D, França E, Abreu D, Araújo V, Bustamante-Teixeira M, Camargos P, da Cunha C, Duncan B, et al. Burden of disease in brazil, 1990-2016: a systematic subnational analysis for the global burden of disease study 2016. Lancet. 2018;392(10149):760-75.

11. Lima-Costa M, de Andrade F, Souza PRBd, Neri A, Duarte YAdO, Castro-Costa E, de Oliveira C. The brazilian longitudinal study of aging (elsi-brazil): objectives and design. Am J Epidemiol. 2018;187(7):1345-53.

12. Lima-Costa M, Firmo J, Uchôa E. The bambuí cohort study of aging: methodology and health profile of participants at baseline. Cadernos de saude publica. 2011;27:327-35.

13. Lebrão M, Duarte YAdO, Teixeira D, Andrade FBd. Saúde bucal nas coortes do estudo sabe (saúde, bem-estar e envelhecimento) em são paulo. Revista Brasileira de Epidemiologia. 2015;18:278-82.

14. Ramos $L$. Fatores determinantes do envelhecimento saudável em idosos residentes em centro urbano: Projeto epidoso, são paulo. Cadernos de Saúde Pública. 2003;19:793-7.

15. Schneider I, Confortin S, Bernardo CdO, Bolsoni C, Antes D, Pereira K, Ono L, Marques L, Borges L, Giehl M, et al. Epifloripa aging cohort study: methods, operational aspects, and follow-up strategies. Revista de saude publica. 2017;51:104.

16. Castro M, Massuda A, Almeida G, Menezes-Filho N, Andrade M, de Souza Noronha KVM, Rocha R, Macinko J, Hone T, Tasca R, et al. Brazil's unified health system: the first 30 years and prospects for the future. Lancet. 2019;394(10195):345-56.

17. Thumé E, Facchini L, Wyshak G, Campbell P. The utilization of home care by the elderly in brazil's primary health care system. Am J Public Health. 2011;101(5):868-74.

18. Macinko J, Harris M. Brazil's family health strategy_delivering community-based primary care in a universal health system. N Engl J Med. 2015:372(23):2177-81.

19. Brazilian Health Ministry. E-Gestor Atenção Básica. Cobertura da atenção básica. 2020. https://egestorab.saude.gov.br/paginas/acessoPublico/ relatorios/relHistoricoCoberturaAB.xhtml. Accessed 20 Sep 2019.

20. dos Santos de Carvalho VCH, Rossato S, Fuchs F, Harzheim E, Fuchs S, et al. Assessment of primary health care received by the elderly and health related quality of life: a cross-sectional study. BMC Public Health. 2013;13(1):1-9.

21. Facchini L, Tomasi E, Dilélio A. Quality of primary health care in brazil: advances, challenges and perspectives. Saúde em Debate. 2018;42: 208-23.

22. Nedel F, Facchini L, Martín-Mateo M, Vieira L, Thumé E. Family health program and ambulatory care-sensitive conditions in southern brazil. Revista de saude publica. 2008;42:1041-52.

23. Brasil V, Costa JSDd. Hospitalizations owing to ambulatory care sensitive conditions in florianopolis, santa catarina-an ecological study, 2001-2011. Epidemiologia e Serviços de Saúde. 2016;25:75-84.

24. Rasella D, Harhay M, Pamponet M, Aquino R, Barreto M. Impact of primary health care on mortality from heart and cerebrovascular diseases in brazil: a nationwide analysis of longitudinal data. BMJ. 2014;348:1-10.

25. Facchini $L$, Piccini $R$, Tomasi $E$, Thumé E, Silveira $D$, Siqueira $F$, Rodrigues M. Performance of the psf in the brazilian south and northeast: institutional and epidemiological assessment of primary health care. Ciên Saú Coletiva. 2006;11:669-81. 
26. Brazilian Institute of Geography and Statistics. @Cidades: Bagé, Rio Grande do Sul. https://cidades.ibge.gov.br/brasil/rs/bage/panorama. Accessed 20 Sep 2019.

27. Brazilian Institute of Geography and Statistics. Municipal Human Development Index (MHDI). http://www.atlasbrasil.org.br. Accessed 20 Sep 2019.

28. Brazilian Health Ministry. Brazilian Public Healthcare Data Repository (DATASUS). Demografic and Socioeconomic Indicators. https://datasus. saude.gov.br/informacoes-de-saude-tabnet/. Accessed 30 July 2008.

29. Thumé E, Facchini L, Tomasi E, Vieira L. Assistência domiciliar a idosos: fatores associados, características do acesso e do cuidado. Rev Saúde Publica. 2010;44:1102-11.

30. Callaway CW, Chumlea WC, Bouchard C. Anthropometric Standardization Reference Manual. In: Lohman TG, Roche AF, Martorell R, editors. Champaign: Human Kinetics Books; 1988. p. 39-54

31. Matsudo S, Araújo T, Matsudo V, Andrade D, Andrade E, Oliveira L, Braggion G. Questionário Internacional de Atividade Fisica (IPAQ): Estudo de validade e reprodutibilidade no Brasil. Rev Ativ Fís Saúde. 2001;6(2): 5-18.

32. Katz S. The index of adl: a standardized measure of biological and psychosocial function. Jama. 1963;185:914-9.

33. Lawton M, Brody E. Assessment of older people: self-maintaining and instrumental activities of daily living. Gerontol. 1969;9(3_Part_1):179-86.

34. Yesavage J, Sheikh J. 9/geriatric depression scale (gds) recent evidence and development of a shorter version. Clin Gerontol. 1986;5(1-2):165-73.

35. Folstein M, Folstein S, McHugh P. "mini-mental state": a practical method for grading the cognitive state of patients for the clinician. J Psychiatr Res. 1975;12(3):189-98.

36. Fleck M, Louzada S, Xavier M, Chachamovich E, Vieira G, Santos L, Pinzon V. Aplicação da versão em português do instrumento abreviado de avaliação da qualidade de vida" whoqol-bref". Revista de saúde pública. 2000;34:178-83.

37. Santos I, Tavares B, Munhoz T, Almeida LSPd, Silva NTBd, Tams B, Patella A, Matijasevich A. Sensitivity and specificity of the patient health questionnaire-9 (phq-9) among adults from the general population. Cadernos de saude publica. 2013;29(8):1533-43.

38. Glasgow R, Wagner E, Schaefer J, Mahoney L, Reid R, Greene S. Development and validation of the patient assessment of chronic illness care (pacic). Med Care. 2005;43(5):436-44.

39. Schofield M, Mishra G. Validity of self-report screening scale for elder abuse: Women's health australia study. Gerontologist. 2003;43(1):110-20.

40. Griep R, Chor D, Faerstein E, Werneck G, Lopes C. Construct validity of the medical outcomes study's social support scale adapted to portuguese in the pro-saude study. Cadernos de saude publica. 2005;21(3):703-14.

41. Holz A, Nunes B, Thume E, Lange C, Facchini L. Prevalence of cognitive impairment and associated factors among the elderly in bagé, rio grande do sul, brazil. Revista Brasileira de Epidemiologia. 2013;16:880-8.

42. Bretanha A, Facchini $L$, Nunes B, Munhoz T, Tomasi E, Thumé E. Sintomas depressivos em idosos residentes em áreas de abrangência das unidades básicas de saúde da zona urbana de bagé, rs. Revista Brasileira de Epidemiologia. 2015;18:1-12.

43. Nunes B, de Oliveira Saes M, Siqueira F, Tomasi E, Silva S, da Silveira D, Soares $M$, Facchini $L$, Thumé E. Falls and self-assessment of eyesight among elderly people: a population-based study in a south brazilian municipality. Arch Gerontol Geriatr. 2014;59(1):131-5.

44. Nunes J, Saes MdO, Nunes B, Siqueira F, Soares D, Fassa M, Thumé E, Facchini L. Indicadores de incapacidade funcional e fatores associados em idosos: estudo de base populacional em bagé, rio grande do sul. Epidemiologia e Serviços de Saúde. 2017;26:295-304.

45. Saes M, Lopes J, Nunes B, Duro S, Facchini L, Thumé E. Occurrence of spinal disorders and associated factors in the elderly: A population study in a municipality in extreme south of brazil. Ciênc Saude Coletiva [online]. 2021;26(2):739-47.

46. Kessler M, Facchini L, Soares M, Nunes B, França S, Thumé E. Prevalence of urinary incontinence among the elderly and relationship with physical and mental health indicators. Revista Brasileira de Geriatria e Gerontologia. 2018;21(4):397-407.

47. Nunes B, Thumé E, Facchini L. Multimorbidity in older adults: magnitude and challenges for the brazilian health system. BMC Public Health. 2015;15(1):1-11.
48. Soares M, Nunes B, Wachs L, Kessler M, Dilélio A, Soares D, Facchini L, Thumé E. Relações sociais informais em idoso com hipertensão e/ou diabetes. Revista de Enfermagem da UFSM. 2018;8(4):780-93.

49. Machado K, Krolow M, Xavier N, Leal C, Gonzalez T, Oliveira A, Wachs L, Soares M, Volz P, Kessler M, et al. Convívio de animais de estimação entre idosos: um estudo de base populacional no sul do brasil. Evidência. 2020;20(2):111-20.

50. Tavares N, Bertoldi A, Thume E, Facchini L, Franca GVAd, Mengue S. Fatores associados à baixa adesão ao tratamento medicamentoso em idosos. Revista de Saúde Pública. 2013;47:1092-101.

51. Nunes B, Soares M, Wachs L, Volz P, Saes MdO, Duro S, Thumé E, Facchini L. Hospitalization in older adults: association with multimorbidity, primary health care and private health plan. Revista de saude publica. 2017;51:43.

52. Kessler M, Thumé E, Scholes S, Marmot M, Facchini L, Nunes B, Machado K, Soares M, de Oliveira C. Modifiable risk factors for 9-year mortality in older english and brazilian adults: The elsa and siga-bagé ageing cohorts. Sci Rep. 2020;10(1):1-13.

53. Soares M, Facchini L, Nedel F, Wachs L, Kessler M, Thumé E. Social relationships and survival in the older adult cohort. Revista Latino-Americana de Enfermagem. 2021;29:

54. Kessler M, Thumé E, Marmot M, Macinko J, Facchini L, Nedel F, Wachs L, Völz P, Oliveira C. Family health strategy, primary health care, and social inequalities in mortality among older adults in Bagé, southern brazil (accepted). Am J Public Health. 2021.

55. Lima-Costa M, Barreto S. Tipos de estudos epidemiológicos: conceitos básicos e aplicações na área do envelhecimento. Epidemiologia e serviços de saúde. 2003;12(4):189-201.

\section{Publisher's Note}

Springer Nature remains neutral with regard to jurisdictional claims in published maps and institutional affiliations.
Ready to submit your research? Choose BMC and benefit from:

- fast, convenient online submission

- thorough peer review by experienced researchers in your field

- rapid publication on acceptance

- support for research data, including large and complex data types

- gold Open Access which fosters wider collaboration and increased citations

- maximum visibility for your research: over $100 \mathrm{M}$ website views per year

At BMC, research is always in progress.

Learn more biomedcentral.com/submissions 